\title{
Survival of some Probiotics in Bio-Yoghurt Production
}

\author{
Amal M. A. Ahmed ${ }^{1 *}$; H. A. El Demerdash ${ }^{1,2}$; M. R. Shahein ${ }^{1}$ and M. M. Metwally ${ }^{1}$ \\ ${ }^{1}$ Department of Food and Dairy Sciences and Technology, Faculty of Environmental Agricultural Sciences, El-Arish \\ University, Egypt. \\ ${ }^{2}$ Biotechnology Research Center, Suez Canal University, Ismailia, Egypt.
}

Received: 4/1/2016

\begin{abstract}
Viability of Lactobacillus acidophilus (L. acidophilus) and Bifidobacterium bifidum (B. bifidum) incorporated with yoghurt culture in three combinations of starter cultures; Treatment 1 (yoghurt culture $+L$. acidophilus), T2 (yoghurt culture + B. bifidum) and T3 (yoghurt culture + L. acidophilus + B. bifidum) were studied. Analyses of $\mathrm{pH}$, titratable acidity (TA), syneresis, acetaldehyde content and sensory evaluation after 1, 3, 7, 14 and 21 days of cold storage of yoghurt were under taken. Counts of L. acidophilus was recorded $5.85 \log _{10} \mathrm{cfu} \mathrm{g}^{-1}$ in $\mathrm{T} 1$ which were higher than counts in T3 $\left(5.79 \log _{10} \mathrm{cfu} \mathrm{g}^{-1}\right)$ at the end of storage period. On the other hand, the viability of $L$. acidophilus and B. bifidum was stable until 14 days of storage period. The results showed that the addition of $B$. bifidum to yoghurt culture (T2) increased TA of bio-yoghurt comparing with addition of L. acidophilus (T1). Syneresis in all treatments was in the range of 20 to $33 \%$ and it was found higher in T3 than control. The highest sensory values were in control, T1 and T2 until the end of 14 days of storage period.
\end{abstract}

Keywords: Yoghurt, Probiotic, Bio-yoghurt.

\section{INTRODUCTION}

Probiotics definition as "live microorganisms which when administered in adequate amounts confer a health benefit on the host" by Food and Agriculture Organization of the United Nations and World Health Organization (FAO/WHO, 2001). An important challenge for industrial producers was viability and stability of probiotic bacteria in their products during either the technology or marketing Caldeano and Perdigon (2004). Probiotic cultures with good technological properties should grow easily in milk, improve sensory characteristics of the product and should be viable during the whole product shelf life (Magarinos et al., 2008). Bifidobacteria and lactobacilli were the famous probiotic bacteria incorporated into dairy products (Lourens-Hattingh and Viljoen, 2001).

The viability of L. acidophilus in bio-yoghurt improved by incorporated into milk with yoghurt culture before fermentation (Tamime, 2005). This allows propagation of $L$. acidophilus to some extent in milk, which improves the initial number after processing and assists its adaptation to the product environment; this will help their survival during storage. The possible interactions between selected strains should be considered when choosing the best combinations in order to optimize their performance in the process and their viability.

Probiotic bacteria must be viable and available at a high concentration, typically $10^{6}-10^{7}$ cfu $\mathrm{g}^{-1}$ of product to achieve health benefits (Shah et al., 2000).

The aim of this work was to determine the viability of probiotic bacteria (L. acidophilus and $B$. bifidum) incorporated with yoghurt starter culture in making bio-yoghurt. To achieve this goal, three different mixtures in addition to control were prepared and their technological properties and sensory evaluation during storage at $4^{\circ} \mathrm{C}$ for 21 days were studied.

\section{MATERIALS AND METHODS}

Bacterial strains:

Streptococcus thermophilus 1043 (S. thermophilus), Lactobacillus delbrueckii ssp. bulgaricus 20080 (L. delbrueckii ssp. bulgaricus) and $L$. acidophilus 20079 were obtained from Ain Shams University, Faculty of Agriculture, Microbiological Resources Center (Cairo MIRCEN). B. bifidum 6071 was procured by China Center of Industrial Culture Collection (CICC), Beijing, China.

\section{Preparation of yoghurt:}

Fresh cow's milk was obtained from the local market. The average of chemical composition of milk was $4.12-4.14,4.0-4.20$ and $11.45-11.50 \%$ for protein, fat and total solids (TS), respectively. Yoghurt was prepared as described by Tamime and Robinson (1985). Briefly, whole cow's milk (3.5\% fat and $12.7 \%$ TS) was heat treated up to $\approx 85^{\circ} \mathrm{C}$ for 10 min then cooled to $42^{\circ} \mathrm{C}$ and inoculated with $2 \%$ of starter culture. Three starter cultures were prepared as following:

Control: Yoghurt culture (S. thermophilus $+L$. delbrueckii ssp. bulgaricus).

T1: Yoghurt culture + L. acidophilus.

T2: Yoghurt culture + B. bifidum.

T3: Yoghurt culture + L. acidophilus + B. bifidum .

All the treatments were distributed into $120 \mathrm{ml}$ sterilized leaded glass cups and incubated at $42^{\circ} \mathrm{C}$ until clotting. Yoghurt was kept at $\approx 5 \pm 11^{\circ} \mathrm{C}$ for 21 days and then the samples were taken when fresh, 3, 7, 14 and 21 days and tested for viable bacterial count, chemical analyses and sensory evaluation.

\section{Microbiological analysis:}

S. thermophilus was enumerated on M17 agar at $37^{\circ} \mathrm{C} / 48$ h. L. delbrueckii ssp. bulgaricus was counted on MRS agar with $\mathrm{pH}$ adjusted to 5.2 at $42^{\circ} \mathrm{C} / 48 \mathrm{~h}$ (Dave and Shah, 1997). MRS-sorbitol agar (1.0\% Dsorbitol) was used for enumerated of L. acidophilus at $37^{\circ} \mathrm{C} / 48 \mathrm{~h}$, while, B. bifidum was enumerated on LPMRS (lithium propionate-MRS) agar in anaerobic jar at 
$37^{\circ} \mathrm{C} / 72 \mathrm{~h}$ has described by Vinderola and Reinheimer (1999).

\section{Chemical analysis:}

The $\mathrm{pH}$ value of the produced bio-yoghurt samples were measured as described by BSI (1985) using Jenco pH meter (model 671P, USA). The titratable acidity was determined according to BSI (2010). Yoghurt was then analyzed for total solids by the method of Kurt et al. (1996). Acetaldehyde content and syneresis of yoghurt were estimated as described by Lees and Jago (1969) and Keogh and O'Kennedy (1998), respectively.

\section{Sensory evaluation:}

The organoleptic properties of fresh and stored bio-yoghurt were carried out according to the procedures of Kebary and Hussein (1999) by the panels of 8 staff members of the Food and Dairy Science and Technology Department, Faculty of Environmental Agriculture, El-Arish University. The sensory attributes included: flavour (50 points), body and texture (30 points) and appearance (20 points).

\section{Statistical analysis:}

Statistical analyses for the obtained data were carried out according to the method described by Clarke and Kempson (1997).

\section{RESULTS AND DISCUSSIONS}

\section{Chemical composition of bio- yoghurt:}

The total solids contents, $\mathrm{pH}$, titratable acidity, syneresis and acetaldehyde content are shown in Table (1). The total solid of all the produced bio-yoghurt were showed slight increase, which was mainly attributed to slight evaporation during cold storage periods. The total solids of produced bio-yoghurt did not affected by the type of starter cultures used. These results were in agreement with that of Cunha et al. (2002).

\section{pH and TA:}

Generally, the greatest drop of $\mathrm{pH}$ was noticeable after 14 days of the storage in all treatments. There were significant differences $(\mathrm{P}<0.05)$ between treatments where the values of $\mathrm{pH}$ were decreased and TA increased. The $\mathrm{pH}$ value was 4.53 in $\mathrm{T} 1$, while it was 4.28 for T3 during the storage period, which was generally considered detrimental to the survival of probiotic bacteria (Dave and Shah, 1997).

Comparing the results of TA according to the added starter cultures, addition of B. bifidum to yoghurt culture (T2) increased TA of bio-yoghurt as compared with the addition of L. acidophilus (T1). These results agreed with Tamime et al. (1995) and Kehagias et al. (2006) which attributed such results to the formation of both acetic and lactic acids by $B$. bifidum. Post acidification of yoghurt treatments is attributed to the metabolic activity of the starter bacteria during the cold storage periods of the product. Also, Beal et al. (1994) reported that post-acidification was greater by using a mixed starter culture $S$. thermophilus with $L$. delbrueckii ssp. bulgaricus than with other bacterial strain associations; this explains the associative growth that exists between these selected bacteria.
Whey syneresis: Syneresis is generally defined as separation of aqueous phase from continuous phase or gel network, which is an undesirable property in fermented milk products (Aghajani et al., 2012). Syneresis of all treatments decreased during storage period. This is accordance with obtained by Isleten and Karagul-Yuceer (2006). Moreover, the acidity of the yoghurt could be a further contributing factor since the increasing in acidity is known to stimulate syneresis in yoghurt and rearrangement of casein particles in the gel network, and the rate of solubilization of colloidal calcium particles are the driving factor for the syneresis (Tamime et al., 1995; Lee and Lucey, 2004).

The high separation of whey was found in T3 followed by control meanwhile, the lowest value was obtained for T1. This could be attributed to the differentiations in metabolic activities of starter cultures. Starter cultures, product type and storage time were effected on syneresis values (Panesar and Shinde, 2012). Some strains of lactic acid bacteria produce exopolysaccharides (EPS) which affect syneresis of fermented products. The EPS have the ability to bind water and reduce syneresis (De Vuyst and Degeest, 1999).

Acetaldehyde content: Acetaldehyde is mainly responsible for the typical aroma of yoghurt. The results showed that there were significant differences $(\mathrm{P}<$ 0.05) of acetaldehyde content among treatments during storage period. After 7 days of cold storage, the highest acetaldehyde values were observed and it was $57.47 \mathrm{mg}$ $\mathrm{g}^{-1}$ for T3, whereas the lowest value was observed for control (54.44 $\left.\mathrm{mg} \mathrm{g}^{-1}\right)$. Therefore, the differences in acetaldehyde contents could be attributed to the differences of starter culture.

The high increase of acetaldehyde content, particularly in T3 may be due to the addition of two strains of probiotic bacteria ( $L$. acidophilus $+B$. bifidum). These results refer to probiotic bacteria which stimulated the growth of yoghurt starter and the acetaldehyde production, these data were in agreement with Murti et al. (1993).

With the progress of storage periods, acetaldehyde content of all treatments started to decrease. The lowest value was $34.03 \mathrm{mg} \mathrm{g}^{-1}$ for control after 21 days. The decrease in the acetaldehyde levels could be related to the hydrolysis by microbial enzymes to form other substances such as converting acetaldehyde to ethanol by the enzymes of yoghurt bacteria. Yuguchi et al. (1989) mentioned that the higher amount of acetaldehyde might be due to the metabolism activity of bifidobacteria.

\section{Microbiological properties of bio-yoghurt:}

In general, there were significant differences $(\mathrm{P}<$ 0.05), in counts of $S$. thermophilus, L. delbrueckii ssp. bulgaricus, L. acidophilus and B. bifidum between treatments when fresh and during storage period (Table 2). 
Table (1): Changes of total solid (TS) $\%, \mathrm{pH}$, titratable acidity $\%$, acetaldehyde contents $\left(\mathrm{mg} \mathrm{g}^{-1}\right)$ and syneresis $\left(\mathrm{ml} 100 \mathrm{~g}^{-1}\right)$ of bio-yoghurt stored at $4^{\circ} \mathrm{C}$ for 21 days

\begin{tabular}{|c|c|c|c|c|c|c|}
\hline \multirow{2}{*}{ Properties } & \multirow{2}{*}{ Treatments ${ }^{*}$} & \multicolumn{5}{|c|}{ Storage period (day) } \\
\hline & & Fresh & 3 & 7 & 14 & 21 \\
\hline \multirow{4}{*}{ TS\% } & $\mathrm{C}$ & $14.94^{\mathrm{b}}$ & $15.43^{b}$ & $15.53^{\mathrm{c}}$ & $15.67^{c}$ & $15.71^{b}$ \\
\hline & T1 & $14.97^{\mathrm{a}}$ & $15.45^{\mathrm{a}}$ & $15.59^{\mathrm{a}}$ & $15.73^{\mathrm{a}}$ & $15.75^{\mathrm{a}}$ \\
\hline & $\mathbf{T 2}$ & $14.96^{\mathrm{a}}$ & $15.44^{\mathrm{a}}$ & $15.56^{\mathrm{b}}$ & $15.69^{b}$ & $15.73^{\mathrm{a}}$ \\
\hline & T3 & $14.93^{\mathrm{b}}$ & $15.43^{\mathrm{b}}$ & $15.52^{d}$ & $15.66^{\mathrm{c}}$ & $15.70^{\mathrm{b}}$ \\
\hline \multirow{4}{*}{ pH } & $\mathbf{C}$ & $4.47^{\mathrm{b}}$ & $4.40^{\mathrm{b}}$ & $4.35^{\mathrm{b}}$ & $4.30^{\mathrm{c}}$ & $4.29^{\mathrm{b}}$ \\
\hline & T1 & $4.53^{\mathrm{a}}$ & $4.44^{\mathrm{a}}$ & $4.39^{\mathrm{a}}$ & $4.34^{\mathrm{a}}$ & $4.31^{\mathrm{a}}$ \\
\hline & $\mathbf{T} 2$ & $4.48^{\mathrm{b}}$ & $4.43^{\mathrm{a}}$ & $4.36^{\mathrm{b}}$ & $4.32^{\mathrm{b}}$ & $4.29^{\mathrm{b}}$ \\
\hline & T3 & $4.45^{\mathrm{c}}$ & $4.38^{\mathrm{c}}$ & $4.34^{\mathrm{c}}$ & $4.28^{\mathrm{d}}$ & $4.28^{\mathrm{c}}$ \\
\hline \multirow{4}{*}{ TA\% } & $\mathbf{C}$ & $0.85^{\mathrm{a}}$ & $0.89^{\mathrm{a}}$ & $0.92^{\mathrm{a}}$ & $0.96^{\mathrm{a}}$ & $1.00^{\mathrm{a}}$ \\
\hline & T1 & $0.79^{\mathrm{c}}$ & $0.83^{\mathrm{c}}$ & $0.86^{\mathrm{b}}$ & $0.91^{\mathrm{c}}$ & $0.94^{\mathrm{c}}$ \\
\hline & $\mathbf{T 2}$ & $0.83^{\mathrm{b}}$ & $0.85^{\mathrm{b}}$ & $0.90^{\mathrm{a}}$ & $0.93^{\mathrm{b}}$ & $0.96^{\mathrm{c}}$ \\
\hline & T3 & $0.82^{\mathrm{b}}$ & $0.84^{\mathrm{cb}}$ & $0.89^{\mathrm{a}}$ & $0.92^{\mathrm{cb}}$ & $0.98^{\mathrm{b}}$ \\
\hline \multirow{4}{*}{$\begin{array}{l}\text { Acetaldehyde contents } \\
\left(\mathrm{mg} \mathrm{g}^{-1}\right)\end{array}$} & $\mathrm{C}$ & $41.75^{\mathrm{c}}$ & $44.96^{\mathrm{d}}$ & $54.44^{\mathrm{c}}$ & $42.94^{c}$ & $34.03^{\mathrm{d}}$ \\
\hline & $\mathbf{T 1}$ & $43.61^{b}$ & $52.57^{\mathrm{c}}$ & $55.25^{\mathrm{b}}$ & $44.47^{\mathrm{b}}$ & $35.94^{\mathrm{c}}$ \\
\hline & $\mathbf{T} 2$ & $43.21^{\mathrm{b}}$ & $53.52^{\mathrm{b}}$ & $56.03^{\mathrm{b}}$ & $48.83^{\mathrm{a}}$ & $37.23^{\mathrm{b}}$ \\
\hline & T3 & $44.37^{\mathrm{a}}$ & $56.08^{\mathrm{a}}$ & $57.47^{\mathrm{a}}$ & $49.48^{\mathrm{a}}$ & $40.62^{\mathrm{a}}$ \\
\hline \multirow{4}{*}{ Syneresis (ml $\left.100 \mathrm{~g}^{-1}\right)$} & $\mathbf{C}$ & $32.28^{\mathrm{b}}$ & $29.64^{b}$ & $26.42^{b}$ & $24.92^{\mathrm{a}}$ & $21.73^{b}$ \\
\hline & T1 & $30.15^{\mathrm{d}}$ & $26.44^{\mathrm{d}}$ & $24.87^{\mathrm{d}}$ & $22.35^{\mathrm{c}}$ & $20.71^{\mathrm{c}}$ \\
\hline & $\mathbf{T 2}$ & $31.63^{\mathrm{c}}$ & $29.53^{\mathrm{c}}$ & $25.67^{\mathrm{c}}$ & $22.27^{\mathrm{d}}$ & $20.11^{\mathrm{c}}$ \\
\hline & T3 & $33.16^{\mathrm{a}}$ & $30.39^{\mathrm{a}}$ & $27.39^{\mathrm{a}}$ & $24.48^{\mathrm{b}}$ & $22.39^{\mathrm{a}}$ \\
\hline
\end{tabular}

"C: (yoghurt starter culture), T1: (yoghurt culture + L. acidophilus), T2: (yoghurt culture + B. bifidum) and T3: (yoghurt culture + L. acidophilus + B. bifidum $)$.Values with different letters in the same column are significantly different $(\mathrm{P}<0.05)$.

Table (2): Survival $\left(\log _{10} \mathrm{cfu}^{-1}\right)$ of $S$. thermophilus, L. delbrueckii ssp. bulgaricus, L. acidophilus and B. bifidum in bio-yoghurt during storage at $4^{\circ} \mathrm{C}$ for 21 days

\begin{tabular}{|c|c|c|c|c|c|c|c|}
\hline \multirow{2}{*}{$\begin{array}{l}\text { Starter } \\
\text { culture }\end{array}$} & \multirow{2}{*}{ Treatments ${ }^{*}$} & \multicolumn{6}{|c|}{ Storage period (day) } \\
\hline & & Fresh & 3 & 7 & 14 & 21 & Mean \\
\hline \multirow{5}{*}{ S. thermophilus } & $\mathbf{C}$ & 9.21 & 8.89 & 8.81 & 8.76 & 8.65 & $8.86^{\mathrm{a}}$ \\
\hline & T1 & 9.01 & 8.93 & 8.80 & 8.74 & 8.56 & $8.80^{\mathrm{a}}$ \\
\hline & $\mathbf{T} 2$ & 8.83 & 8.75 & 8.63 & 8.57 & 8.48 & $8.65^{\mathrm{a}}$ \\
\hline & T3 & 8.86 & 8.82 & 8.75 & 8.67 & 8.53 & $8.72^{\mathrm{a}}$ \\
\hline & $\mathbf{C}$ & 8.07 & 7.94 & 7.78 & 7.62 & 7.43 & $7.76^{b}$ \\
\hline \multirow{3}{*}{$\begin{array}{l}\text { L. delbrueckii ssp. } \\
\text { bulgaricus }\end{array}$} & T1 & 7.95 & 7.46 & 7.52 & 7.03 & 6.83 & $7.35^{\mathrm{b}}$ \\
\hline & $\mathbf{T} 2$ & 7.85 & 7.81 & 7.76 & 7.66 & 7.58 & $7.73^{b}$ \\
\hline & $\mathbf{T 3}$ & 7.73 & 7.58 & 7.43 & 7.28 & 6.92 & $7.38^{\mathrm{b}}$ \\
\hline \multirow{2}{*}{ L. acidophilus } & T1 & 7.41 & 7.30 & 7.09 & 6.76 & 5.85 & $6.88^{\mathrm{c}}$ \\
\hline & T3 & 7.34 & 7.25 & 7.08 & 6.57 & 5.79 & $6.80^{\mathrm{c}}$ \\
\hline \multirow{2}{*}{ B. bifidum } & $\mathbf{T} 2$ & 7.48 & 7.12 & 6.80 & 6.65 & 6.53 & $6.91^{\mathrm{c}}$ \\
\hline & T3 & 6.83 & 6.81 & 6.76 & 6.18 & 5.73 & $6.46^{\mathrm{c}}$ \\
\hline
\end{tabular}

"C: (yoghurt starter culture), T1: (yoghurt culture + L. acidophilus), T2: (yoghurt culture + B. bifidum) and T3: (yoghurt culture + L. acidophilus + B. bifidum $)$. Values with different letters in the same column are significantly different $(\mathrm{P}<0.05)$. 


\section{Counts of yoghurt culture:}

The average of initial microbial count for each of the activated cultures was $10^{7} \mathrm{cfu} \mathrm{g}^{-1}$. After $24 \mathrm{~h}$ of fermentation, the counts (log values) were 9.21 and 8.07 for $S$. thermophilus and $L$. delbrueckii ssp. bulgaricus, respectively. The values of $S$. thermophilus and $L$. delbrueckii ssp. bulgaricus were decreased by 0.56 and 0.64 cycles, respectively after 21 days of the storage period. The symbiotic nature of yoghurt culture shows that $S$. thermophilus produces lactic acid, pyruvic acid, formic acid and $\mathrm{CO}_{2}$. Lactic and formic acids stimulate the growth of $L$. delbrueckii ssp. bulgaricus and also, $S$. thermophilus create favorable conditions for the growth of $L$. delbrueckii ssp. bulgaricus throughout assimilates oxygen in milk which in turn produces peptides and amino acids that stimulate the growth of $S$. thermophiles (Radke-Michell and Sandine, 1984).

$S$. thermophilus was obviously dominated in yoghurt and bio-yoghurt. Oliveira et al. (2002) reported that $S$. thermophilus predominated in all products presenting counts higher than $9 \log _{10} \mathrm{cfu} \mathrm{m}^{-1}$ in yoghurt prepared with mixed culture. However, by the end of the storage period, the counts decreased to $8.65,8.56$, 8.48 and $8.53 \log _{10} \mathrm{cfu} \mathrm{ml}^{-1}$ in control, T1, T2 and T3 treatments, respectively. Birollo et al. (2000) observed that $S$. thermophilus remained viable $\left(10^{9} \mathrm{cfu} \mathrm{ml}^{-1}\right)$ after 40 days of storage period at $6^{\circ} \mathrm{C}$. On other hand, $L$. delbrueckii ssp. bulgaricus counts reached $10^{8} \mathrm{cfu} \mathrm{ml}^{-1}$ within the first 10 days, under the same storage conditions, and after 15 to 45 days the counts continued to be $10^{7} \mathrm{cfu} \mathrm{ml}^{-1}$.

During the storage course, the viability of $L$. delbrueckii ssp. bulgaricus was reduced by $1.19 \log _{10}$ cfu $\mathrm{g}^{-1}$ when grown with $S$. thermophilus. Venir et al. (2007) found in fresh yoghurt, $S$. thermophilus counts between $10^{4}-10^{8} \mathrm{cfu} \mathrm{ml}^{-1}$ and $10^{6}-10^{7} \mathrm{cfu} \mathrm{ml}^{-1}$ for $L$. delbrueckii ssp. bulgaricus. In this study, yoghurt culture count was 8.53-9.21 and 6.83-8.07 $\log$ cfu g $^{-1}$ for S. thermophilus and L. delbrueckii ssp. bulgaricus, respectively.

\section{L. acidophilus of bio-yoghurt:}

L. acidophilus showed a steady decline in counts during the interval storage periods and contained $>10^{6}$ cfu $\mathrm{g}^{-1}$ for 14 days of storage period. This result was mainly attributed to low $\mathrm{pH}$ values and organic acids accumulation in which they are amongst the important factors contributing to the loss of cell viability of probiotics. This data are in agreement with Nighswonger et al. (1996) and Donkor et al. (2006). The decrease of $L$. acidophilus counts was in agree with Zacarchenco and Massaguer-Roig (2004) who observed a reduction of $2 \log _{10}$ cycles $\mathrm{ml}^{-1}$ in the counts of $L$. acidophilus when grown with $S$. thermophilus and $B$. longum at the end of the storage period. The growth of L. acidophilus in $\mathrm{T} 1\left(5.85 \log _{10} \mathrm{cfu} \mathrm{g}^{-1}\right)$ was higher than that of T3 (5.79 $\left.\log _{10} \mathrm{cfu} \mathrm{\textrm {g } ^ { - 1 }}\right)$ at the end of storage period. On the other hand, Gilliland and Speck (1977) reported that hydrogen peroxide, a substance produced by L. delbrueckii ssp. bulgaricus metabolism, was the main chemical compound responsible for the reduction of L. acidophilus viability in yoghurt.

\section{B. bifidum of bio-yoghurt:}

Several factors have been claimed to be responsible for the loss of viability of probiotic organisms: acidity of products, acid produced during refrigerated storage (post acidification), level of oxygen in products, oxygen permeation through the package, sensitivity to antimicrobial substances produced by bacteria (Dave and Shah, 1997). Counts of B. bifidum remained at $7 \log _{10} \mathrm{cfu} \mathrm{g}^{-1}$ from an initial inoculum of 7 $\log _{10} \mathrm{cfu} \mathrm{g}^{-1}$ during 3 days of cold storage and decreased up to the end of the storage periods to reached $6.53 \log _{10}$ $\mathrm{cfu} \mathrm{g}^{-1}$ in T2 and reduced to $5.73 \log _{10} \mathrm{cfu} \mathrm{g}^{-1}$ in T3.

However, the addition of $S$. thermophilus may also increase the survival of certain strains of Bifidobacterium through the reduction of oxygen pressure as mentioned by Ishibashi and Shimamura (1993) and Nogueira et al. (1998).

The counts of viable $L$. acidophilus and B. bifidum were more than $10^{6} \mathrm{cfu}^{-1}$ until 14 days of storage period in all treatments. These counts were decreased to less than $10^{6} \mathrm{cfu} \mathrm{g}^{-1}$ after 21 days of storage period in all treatments except $\mathrm{T} 2$.

\section{Sensory evaluation:}

The scores of sensory evaluations of bio-yoghurt during storage at $\approx 5 \pm 1^{\circ} \mathrm{C}$ for 21 days are presented in Table (3). Generally, all samples were acceptable by the sensory evaluation panelests. The storage was the principle factor influencing the sensory properties, this may be attributed to the developed acidity and whey separation, which may participated the pleasant acid flavour of yoghurt. Similar observations were reported by Routray and Mishra (2011) who found that the storage time had a negative impact on the flavour scores of yoghurt, thereby attributed to the changes in the aroma compounds.

Significant differences $(\mathrm{P}<0.05)$ were observed among all the treatments. The results showed that addition of $B$. bifidum to yoghurt culture in T2 was most preferable bio-yoghurt from sensory properties than the addition of L. acidophilus in T1. The highest score was 97.16 points for $\mathrm{T} 2$ containing $B$. bifidum followed by T1 containing L. acidophilus with 96.53 points. Bioyoghurt made with $L$. acidophilus or B. bifidum had the highest score for flavour acceptability than other treatments. High flavour acceptability of yoghurt made with probiotic bacteria could be due to their acetaldehyde contents. These data are in agreement with Tawfik et al. (2003) who suggested that the combination of yoghurt culture bacteria with bifidobacteria produced fermented dairy products with preferable flavour and presence of acetaldehyde was the important component for good yoghurt flavour, and Ayad et al. (2010) reported that using B. bifidum with yoghurt culture enhanced body and texture of all treatments. Hassan et al. (2003) indicated that the texture of yoghurt results from a complex interaction between milk protein, acid and exocellular polysaccharide produced by the starter culture. As storage progressed the texture score decreased in bioyoghurt. This could be attributed to that the level of metabolites (mainly acetic acid) produced by the bacterial strains which can influence the organoleptic assessment. 
Table (3): Sensory evaluation scores of bio-yoghurt stored at $5 \pm 1^{\circ} \mathrm{C}$ for 21 days

\begin{tabular}{|c|c|c|c|c|c|}
\hline \multirow{2}{*}{$\begin{array}{l}\text { Storage } \\
\text { period (day) }\end{array}$} & \multirow{2}{*}{ Treatments ${ }^{*}$} & Flavour & Body \& texture & Appearance & Total score \\
\hline & & 50 points & 30 points & 20 points & 100 \\
\hline \multirow{5}{*}{ Fresh } & $\mathbf{C}$ & 48.20 & 28.00 & 19.33 & $95.53^{\mathrm{a}}$ \\
\hline & $\mathbf{T 1}$ & 49.00 & 29.00 & 18.33 & $96.53^{\mathrm{a}}$ \\
\hline & $\mathbf{T} 2$ & 49.00 & 29.00 & 19.16 & $97.16^{\mathrm{a}}$ \\
\hline & T3 & 47.66 & 27.50 & 18.33 & $93.49^{b}$ \\
\hline & $\mathbf{C}$ & 47.83 & 28.00 & 19.33 & $94.16^{\mathrm{b}}$ \\
\hline \multirow{3}{*}{3} & T1 & 48.66 & 29.00 & 18.33 & $95.99^{\mathrm{a}}$ \\
\hline & $\mathbf{T} 2$ & 48.66 & 29.00 & 19.33 & $96.99^{\mathrm{a}}$ \\
\hline & T3 & 45.16 & 27.50 & 16.66 & $89.32^{\mathrm{c}}$ \\
\hline \multirow{5}{*}{7} & $\mathbf{C}$ & 46.33 & 27.33 & 18.50 & $92.16^{\mathrm{b}}$ \\
\hline & T1 & 47.50 & 28.00 & 17.83 & $93.33^{\mathrm{b}}$ \\
\hline & $\mathbf{T} 2$ & 47.50 & 28.16 & 18.50 & $94.16^{\mathrm{b}}$ \\
\hline & $\mathbf{T 3}$ & 45.33 & 26.16 & 17.16 & $88.65^{\mathrm{c}}$ \\
\hline & $\mathbf{C}$ & 44.66 & 26.00 & 17.33 & $87.99^{c}$ \\
\hline \multirow{3}{*}{14} & T1 & 45.16 & 26.50 & 17.00 & $88.66^{\mathrm{c}}$ \\
\hline & $\mathbf{T} 2$ & 45.00 & 26.33 & 17.16 & $88.49^{c}$ \\
\hline & $\mathbf{T 3}$ & 43.33 & 24.50 & 15.33 & $83.16^{\mathrm{d}}$ \\
\hline \multirow{4}{*}{21} & $\mathbf{C}$ & 41.00 & 25.00 & 15.83 & $81.83^{\mathrm{d}}$ \\
\hline & T1 & 43.66 & 24.33 & 15.83 & $83.82^{\mathrm{d}}$ \\
\hline & $\mathbf{T} 2$ & 44.00 & 24.83 & 15.83 & $84.66^{\mathrm{d}}$ \\
\hline & $\mathbf{T 3}$ & 41.33 & 22.00 & 13.66 & $76.99^{\mathrm{d}}$ \\
\hline
\end{tabular}

*C: (yoghurt starter culture), T1: (yoghurt culture + L. acidophilus), T2: (yoghurt culture + B. bifidum) and T3: (yoghurt culture + L. acidophilus + B. bifidum $)$. Values with different letters in the same column are significantly different $(\mathrm{P}<0.05)$.

The results indicated that treatment 2 (yoghurt culture and B. bifidum) and treatment 1 (yoghurt culture and L. acidophilus) were the best combination of starter culture in bio-yoghurt production due to the viability, technological properties and sensory evaluation. At the same time, bio-yoghurt should be consumed until 14 days of storage period to achieve the acceptable standard viable counts of probiotics.

\section{REFERENCES}

Aghajani, A. R., R. Pourahmad and H. R. Mahdavi Adeli (2012). Evaluation of physicochemical changes and survival of probiotic bacteria in synbiotic yoghurt. Journal of Food Biosciences and Technology, 2: 13-22.

Ayad E., A. Darwish, S. Darwish and M. El-Soda (2010). Production of novel functional yoghurtlike products. Egyptian Journal of Dairy Science, 38: 183-199.

Beal, C., N. Deschamps, V. Juillard, H. De Roissart, J. Richard and B. Saraux (1994). Cinetiques de croissance et d'aciditification des bacteries lactiques. In Bacteries lactiques, Aspects Fondamentaux et Technologiques. De Roissart, H. and F. M. Luquet, (Eds), pp. 367-401. Uriage, FRA: Lorica.
Birollo, G. A., L. A. Reinheimer and C. G. Vinderola (2000). Viability of lactic acid microflora in different types of yoghurt. Food Research International, 33: 799-805.

BSI (British Standards Institution) (1985). Determination of $\mathrm{pH}$ value. BS770, Part 5.

BSI (2010). Milk and dried milk: determination of titratable acidity (Reference method) ISO, 6091.

Caldeano, C. M. and G. Perdigon (2004). Role of viability of probiotic strains in their persistence in the gut and in mucosal immune stimulation, Journal Appl. Microbial, 97: 673-681.

Clarke, G. M. and R. E. Kempson (1997). Introduction to the design and analysis of experiments. Arnold, a member of the Holder Headline Group, $1^{\text {st }}$ eds., London, UK.

Cunha, C. R., L. M. Spadoti, P. B. Zacarchenco and W. H. Viotto (2002). Efeito do fator de concentracao do retentado na composicao e proteolise de queijo minas frescal de baixo teor de gordura fabricado por ultrafiltracao. Cienciae Tecnologia de Alimentos, 22: 82-87.

Dave, R. I. and N. P. Shah (1997). Viability of yoghurt and probiotic bacteria in yoghurts made from commercial starter cultures. International Dairy Journal, 7: 31-41. 
De Vuyst, L. and B. Degeest (1999). Heteropolysaccharides from lactic acid bacteria. FEMS Microbiology Reviews. 23: 153-177.

Donkor, O. N., A. Heuriksson, T. Vasiljevic and NP. Sha (2006). Effect of acidification on the activity of probiotics in yoghurt during cold storage. International Dairy Journal, 16: 11811189.

FAO/WHO (Food and Agriculture Organization of the United Nations and World Health Organization) (2001). Health and nutrition properties of probiotics in food including powder milk with live lactic acid bacteria. pp. 2.

Gilliland, S. E. and L. M. Speck (1977). Instability of Lactobacillus acidophilus in yoghurt. Journal of Dairy Science, 60: 1395-1398.

Hassan, A. N., R. Ipsen, T. Janzen and K. B. Qvist (2003). Microstructure and rheology of yoghurt made with cultures differing only in their ability to produce exopolysaccharides. Journal Dairy Science, 86: 1632-1638.

Ishibashi, N. and S. Shimamura (1993). Bifidobacteria: Research and development in Japan. Food Technology, 47: 129-134.

Isleten, M. and Y. Karagul-Yuceer (2006). Effects of dried dairy ingredients on physical and sensory properties of nonfat yoghurt. Journal Dairy Science, 89: 2865-2872.

Kebary, K. M. K. and S. A. Hussein (1999). Manufacture of low fat Zabady using different fat substitutes. Acta Alimentaria Budapest, 28: $1-14$

Kehagias, C., S. Koulouris, J. S. Arkoudelos and A. Samona (2006). Viability and biochemical activity of bifidobacteria in association with yoghurt starter cultures in Bifidus milk and bioyoghurt during storage at $4^{\circ} \mathrm{C}$. Egyptian Journal of Dairy Science, 34: 151-158.

Keogh, M. K. and B. T. O'Kennedy (1998). Rheology of stirred yogurt as affected by added milk fat, protein and hydrocolloids. Journal of Food Science, 63: 108-112.

Kurt, A., S. Cakmakci and A. Caglar (1996). Sutve Mamiilleri Muayeneve Analiz Metotlan Rehberi. Ataturk Univ, Yay. No: 252/d, Erzurum, Turkey.

Lees, G. J. and G. R. Jago (1969). Methods for the estimation of acetaldehyde in cultured dairy products. Australian Journal of Dairy Technology, 24: 181-185.

Lee, W. J. and J. A. Lucey (2004). Structure and physical properties of yoghurt gels: Effect of inoculation rate and incubation temperature. Journal Dairy Science, 87: 3153-3177.

Lourens-Hattingh, A. and B. C. Viljoen (2001). Yoghurt as probiotic carrier food, International Dairy Journal, 11: 1-17.

Magarinos, H., P. Cartes, B. Fraser, S. Selaive, M. Costa, F. Figuerola and O. Pizarro (2008). Viability of probiotic microorganisms (Lactobacillus casei Shirota and Bifidobacterium animalis Subspp. lactis) in a milk-based dessert with cranberry sauce.
International Journal of Dairy Technology, 61: 96-101.

Murti, T. W., C. Bouillanne, M. Landon and M. J. Desmazeaud (1993). Bacterial growth and volatile compounds in yoghurt-type products from soymilk containing Bifidobacterium ssp. Journal of Food Science, 58:153-157.

Nighswonger, B. D., M. M. Brashears and S. E. Gilliland (1996). Viability of L. acidophilus and $L$. casei in fermented milk products during refrigerated storage. Journal of Dairy Science, 79: 212-219.

Nogueira, C., H. Albano, P. Gibbs and P. Teixeira (1998). Microbiological quality of Portuguese yoghurts. Journal of Industrial Microbiology and Biotechnology, 21: 19-21.

Oliveira, M. N., I. Sodini, F. Remeuf, J. P. Tissier and G. Corrieu (2002). Manufacture of fermented lactic beverages containing probiotic cultures. Journal of Food Science, 67: 2336-2341.

Panesar, P. S. and C. Shinde (2012). Effect of storage on syneresis, $\mathrm{pH}$, Lactobacillus acidophilus count, Bifidobacterium bifidum count of Aloe vera fortified probiotic yoghurt. Current Research in Dairy Science, 4: 17-23.

Radke-Michell, L. and W. E. Sandine (1984). Associative growth and differential enumeration of Streptococcus thermophilus and Lactobacillus bulgaricus: A Review Journal Food Prot., 12: 383-391

Routray, W. and H. N. Mishra (2011). Scientific and technical aspects of yoghurt aroma and taste: A Review. Comprehensive Reviews Food Science and Food Safety, 10: 208-220.

Shah, N. P. (2000). Probiotic bacteria: selective enumeration and survival in dairy foods. Journal Dairy Science, 83: 894-907.

Shah, N. P., J. F. Ali and R. K. Ravula (2000). Populations of L. acidophilus, Bifidobacterium spp., and Lactobacillus casei in commercial fermented milk products. Biosciences Microflora, 19: 35-39.

Tamime, A. Y. (2005). Probiotic dairy products, Oxford, UK: Blackwell Publishing Ltd, PP 41.

Tamime, A. Y. and R. K. Robinson (1985). Yoghurt: Science and Technology. Oxford, Pergamon Press Ltd.

Tamime A. Y., V. M. Marshal and R. K. Robinson (1995). Microbiological and technology aspects of milks fermented by bifidobacteria. Journal of Dairy Research, 62: 151-187.

Tawfik, N. F., O. M. Sharaf, G. A. Amin, G. M. Khalafalla, S. A. El-Gizawy and B. A. Azzat (2003). Utilization of some microorganisms as dietary adjuncts ш. Production and application. Egyptian Journal Dairy Science, 31: 221-231.

Venir, E., M. D. Torre, M. L. Stecchini, E. Maltini and P. D. Nardo (2007). Preparation of freeze-dried yoghurt as a space food. Journal of Food Engineering, 80: 402-407.

Vinderola, C. G. and J. A. Reinheimer (1999). Culture media for the enumeration of Bifidobacterium bifidum and Lactobacillus acidophilus in the 
presence of yoghurt bacteria. International Dairy Journal, 9: 497-505.

Yuguchi, H., A. Hiramatsu, K. Doi and O. S. Idach (1989). Studies on the flavor of yoghurt fermented with Bifidobacteria: Significance of volatile components and organic acids in the sensory acceptance of yoghurt. Journal Zootech. Science, 60: 734-741.

Zacarchenco, P. B and S. Massaguer-Roig (2004). Differential enumeration of Bifidobacterium longum and Lactobacillus acidophilus in the presence of Streptococcus thermophilus. Milchwissenschaft, 59: 258-261.

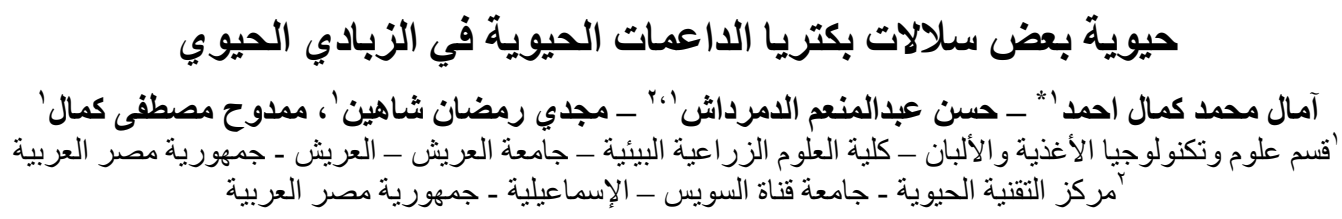

تم إنتاج ثناث معاملات مختلفة من الزبادي الحيوي باستخدام سلالتين من بكتريا البروبيوتك

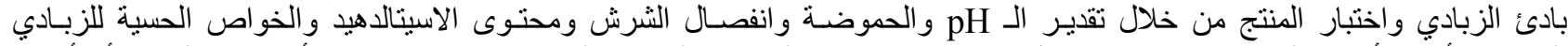

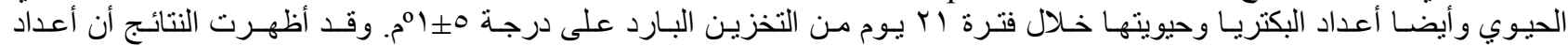

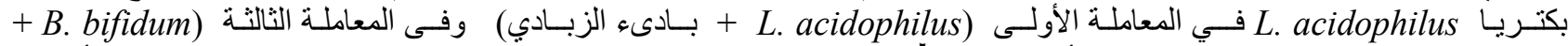
(بادى + L. acidophilus

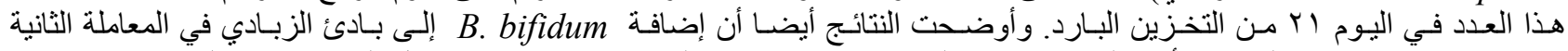
بادى + B. bifidum)

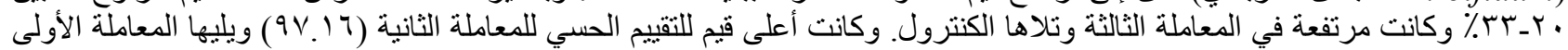

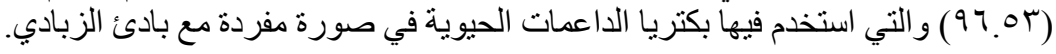

